\title{
TINJAUAN SISTEM CAISSON PADA PENYAMBUNGAN BLOK LAMBUNG KAPAL
}

\author{
Bambang Sudjasta \\ Fakultas Teknik Universitas Pembangunan Nasional "Veteran" Jakarta \\ Program Studi Teknik Perkapalan \\ email : karebet_m@yahoo.co.id
}

\begin{abstract}
To spur the development of the shipbuilding industry efficient and effective, then one will have to do is select the appropriate application of technology to existing conditions. Selection of the technology is closely related to the technical aspects in the field. National shipyards often get the order the construction of new ships with a capacity that exceeds the shipyard conditions. Based on limited means, but the implementation of the construction of ships should still be able to walk then attempted to carry out the connection of the hull below the water. With the adoption of block module, where assembly of the hull is divided into two parts, the module block bow and stern module block. Block modules separate hull is launched/lowered into the water, and then later made the connection in the water. As tools for splicing in the water system been caisson. Serves as a tool in connecting module block in the water then the caisson system must meet requirements such as: 1. The shape of the surface to be attached to the hull should have the same shape as the shape of the ship body. 2. Structure of the caisson to be strong enough. 3. The caissons must have stability and buoyancy are pretty good. In planning is the preparation before the second block of the module is launched into the waters, such as: 1. Determination of the number and dimensions of the hinge. 2. Determination of welding procedures. The process of implementing these connections include: 1. Control of the position of the module block such that the connections between the two. 2. Installation of the amplifier while. 2. Installation of the caisson continued process of welding the hull. 3. Examination of the results of the weld joint.
\end{abstract}

Keywords: Ships, Shipyard, Production

\section{PENDAHULUAN}

\section{Latar Belakang}

Teknologi yang berdaya guna dicerminkan dengan dapatnya diterapkan dalam proses produksi pada bidang industri. Melalui penerapan teknologi maka faktor tenaga kerja, sarana serta biaya tidak memerlukan perubahan struktur yang besar. Berhasil guna dimaksudkan di sini adalah teknologi itu mampu menciptakan produk secara sempurna.

Dalam strategi pembangunan Nasional, industri perkapalan memegang peranan yang cukup penting baik untuk sistem pertahanan keamanan, kelancaran mekanisme perdagangan, maupun kelancaran pembangunan pada umumnya. Oleh karenanya, sektor industri ini dikembangkan dan terus ditingkatkan untuk memenuhi kebutuhan. Melalui peningkatan fasilitas dan sarana produksi, peningkatan teknologi, pemberian peluang yang seluasluasnya bagi pengembangan industri baru, usaha peningkatan industri kapal juga diorientasikan untuk mengoptimalkan potensi produksi kapal nasional serta mengurangi ketergantungan terhadap produk dari luar.

\section{Perumusan Masalah}

Pembangunan kapal 3000 Dwt dengan panjang 91,30 $\mathrm{m}$ di galangan kapal PT. Dok dan Perkapalan Kodja Bahari (PT. DKB) Persero dihadapkan dengan sarana galangan yang terbatas. Keterbatasan tersebut adalah fasilitas peluncuran yang hanya mampu melayani bangunan kapal dengan panjang maksimal 68,00 m. Keterbatasan tersebut harus disikapi dengan "Penentuan Aliran Produksi", sehingga dengan demikian dapat melayani pembangunan kapal yang lebih panjang. Solusi yang diambil adalah dengan melakukan penyambungan lambung kapal di air. Perakitan lambung kapal cargo yang dilakukan di atas building berth dibagi dua bagian. Kedua bagian itu masing-masing disebut modul haluan dan modul buritan diluncurkan ke air secara 
terpisah untuk selanjutnya dilaksanakan penyambungan di perairan. Melalui pengkajian pada aspek teknis, biaya dan peluang di masa mendatang, selanjutnya sistem Caisson dipilih sebagai alat bantu dalam implementasi penyambungan kapal.

\section{Tujuan Penelitian}

1. Tinjauan proses produksi bangunan kapal dibagi menjadi 2 (dua) konstruksi modul.

2. Tinjauan proses penyambungan modul lambung kapal di air dengan alat bantu sistem caisson dipandang sebagai bagian yang integral pada proses penyambungan lambung kapal tersebut di air.

\section{TINJAUAN PUSTAKA}

\section{Sistem Proses Produksi}

Pendekatan secara sistem merupakan pandangan yang melihat semua kegiatan barlangsung dalam susunan yang efisien dan optimum. Seperti halnya dengan proses produksi pada industri perkapalan juga dapat dilihat sebagai sistem, ditunjukkan Bagan Proses Produksi dalam bentuk sederhana.

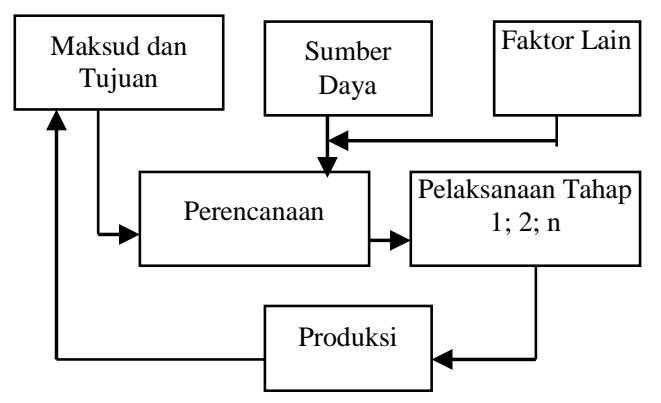

Gambar 1. Bagan Proses Produksi

Dilihat dari segi prosesnya, dalam industri perkapalan telah dikenal beberapa sistem pembangunan. Ada tiga sistem yang popular di Indonesia hingga dekade ini yaitu sistem komponen, sistem seksi, dan sistem blok. Disamping itu ada satu sistem yang baru dan mulai diterapkan yaitu sistem modul.

Perubahan sistem yang berjalan dari waktu ke waktu merupakan hasil evaluasi dan peningkatan atau pengembangan dari sistem sebelumnya.

\section{Sistem Modul}

Kontruksi bangunan sebuah kapal terdiri atas: lunas (keel), wrang (floor), penumpu (girder), pelat alas (bottom plate), gading-gading (frame), sekat (bulkhead), balok geladak (deck girder), pelat geladak (deck plate), pelat kulit (shell plate), linggi haluan (forepeak), linggi buritan (afterpeak), bangunan atas (superstructure) dan rumah geladak (deck house).

Perakitan badan kapal atau erection di atas landasan pembangunan (building berth) merupakan pekerjaan penyambungan antara seksi-seksi yang telah dirakit sebelumnya di bengkel. Pemasangan perlengkapan atau outfitting dilakukan bersamaan di dalam seksiseksi yang selesai dipasang.

Secara eksplisit, pekerjaan pembangunan kapal dengan sistem seksi mengikuti urutanurutan sebagai berikut:

1. Fabrikasi komponen konstruksi.

2. Assembly komponen menjadi seksi.

3. Erection dengan merangkai seksi demi seksi.

4. Outfitting (pemasangan perlengkapan).

Dengan sistem pembangunan kapal di atas, pekerjaan dapat dilakukan pada satu bidang kerja yang luas sehingga waktu pembuatan lebih singkat. Deformasi akibat pengelasan juga dapat dikurangi.

Dibandingkan dengan sistem komponen, kekurangan sistem seksi ini terletak pada aspek sarana dan fasilitas kerja serta teknologinya .Crane atau alat angkat yang digunakan harus dengan daya angkat yang besar. Untuk menjamin ketelitian pekerjaan, dibutuhkan teknologi yang maju.

Proses pembangunan kapal sistem modul ini, badan kapal dibagi ke dalam beberapa bagian modul. Setiap modul pada pokoknya terdiri dari sejumlah seksi / blok termasuk perlengkapan (Outfit). Dalam pelaksanaannya, pembangunan dilakukan secara pararel untuk masing-masing modul.

Bagian-bagian pekerjaan untuk setiap tahapan pekerjaan adalah sebagai berikut:

1. Fabrikasi:
a. Pemotongan dan pembentukan komponen konstruksi lambung.
b. Pembuatan bagian perlengkapan (outfit).

2. Sub assembly:
a. Perakitan seksi-seksi / blok-blok.
b. Pemasangan komponen outfitt.
c. Pengecatan.

3. Assembly:
a. Pembentukan modul-modul.
b. Pemasangan komponen outfit.
c. Pengecatan. 
4. Erection:

Pekerjaan akhir yakni penyambungan antara modul.

Pada uraian di atas telah jelas bahwa karakteristik dasar sistem modul adalah pelaksanaan pekerjaan konstruksi, outfit dan pengecatan yang terintegrasi.

Dipandang dari aspek teknik disain dan produksi, dapatlah dipahami bahwa untuk menerapkan sistem modul harus didukung oleh faktor-faktor, antara lain:

1. Areal galangan yang luas.

2. Fasilitas bengkel yang lengkap.

3. Disain engineering dengan teknologi yang modern.

Keuntungan yang dapat diperoleh dengan sistem ini antara lain adalah daya produksi yang tinggi baik bobot bangunan maupun waktu.

\section{Metode Penyambungan}

Metode penyambungan yaitu dengan penerapan sistem blok modul yang perakitan lambung kapal dibagi dalam dua bagian yaitu blok modul haluan dan blok modul buritan. Persiapan penyambungan harus diperhatikan, seperti nat joint yang pas, keel deflexion dan lain-lain. Selanjutnya penyambungan dilakukan di ruang dalam air dengan menggunakan alat bantu penyambungan tersebut adalah sistem caisson. Caisson mempunyai bentuk yang sama dengan bentuk lambung kapal, karena nanti caisson merupakan alat bantu angkat kapal tersebut, sehingga caisson ini harus diposisikan di bawah lambung kapal.

Namun sebagai persiapannya, modul blok lambung tersebut dipasang sejumlah engsel pada dek, pada masing-masing modul blok tersebut. Dalam memposisikan sejajar ke dua modul blok tersebut dengan mengisi air ballast pada doub!e bottom ke dua modul blok hingga sumbu lubang engsel berada pada satu garis.

Bila pasangan-pasangan setiap engsel telah terpasang, secara perlahan-lahan air ballast yang ada pada kedua bagian dasar ganda masingmasing modul lambung tersebut dikeluarkan, dengan demikian dengan sendirinya bagian bawah kapal akan menyatu untuk selanjutnya caisson diposisikan pada sambungan kedua modul tersebut dengan cara mengisi air ballast pada tangki caisson hingga tenggelam, caisson tersebut di posisi yang tepat, kemudian ballats dikeluarkan hingga terangkat sampai pada keadaan yang aman, baru dilakukan pengelasan.

\section{Sistem Caisson}

Caisson adalah suatu alat apung berbentuk seperti kotak besar, memiliki ruangan/kompartemen (ruang kerja) kedap air yang dapat diapungkan dan ditenggelamkan, serta mempunyai kontur / bibir permukaan sesuai dengan permukaan bawah air dari suatu alat apung lainnya. Suatu ruangan yang besar dan kedap air, yang digunakan untuk melakukan pekerjaan terhadap suatu bangunan (konstruksi) yang berada di bawah air (terendam air).

Proses di mana caisson tersebut dapat tenggelam dan mengapung, karena di dalam caisson dilengkapi dengan sistem pipa dan pompa yang digunakan untuk memasukkan dan mengeluarkan air ke dalam tangkitangki/kompartemennya tersebut.

Standar mutu pengelasan dan prosedur dalam proses pembuatan alat bantu kerja, caisson ini menggunakan bahan utama lembaran pelat baja dan profile baja. Karena tempat operasi floating dock di perairan air laut, maka baja yang digunakan harus dengan standard marine used, dan dalam proses penyambungan menggunakan las dengan standard class regulation yang digunakan untuk kapal baja.

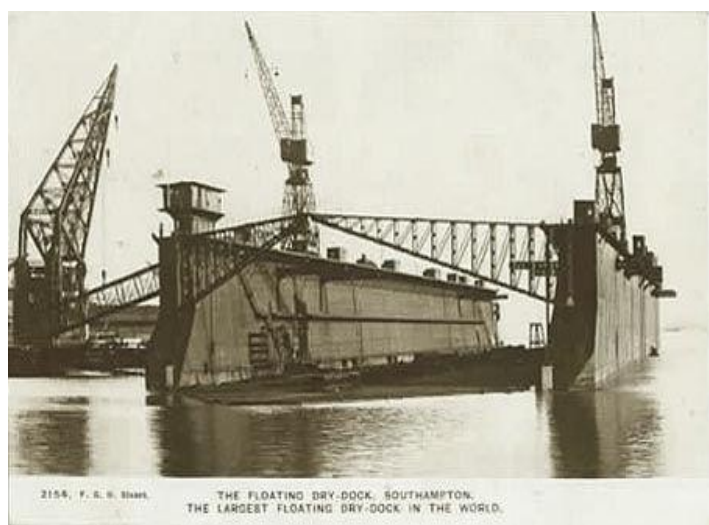

Gambar 1. Penampang Melintang Caisson

\section{Keuntungan dan Kerugian Caisson}

Adapun keuntungan dan kerugian

Casisson adalah sebagai berikut:

1. Keuntungan Caisson

a. Penyambungan dan perbaikan kapal bisa dilakukan di bawah air, jadi tidak perlu naik dok (biaya doking tidak ada).

b. Caisson dapat dipindah-pindahkan, sehingga dapat memperbaiki kapal yang lainnya.

c. Dalam waktu jangka panjang, Caisson dapat digunakan untuk melakukan perbaikan \& perawatan secara 
berkelanjutan terhadap kapal dan alat apung lainnya.

2. Kerugian Caisson

a. Cara pengoperasian Caisson memerlukan perhatian khusus.

b. Karena kerterbatasan ukuran Caisson maka pekerjaan dilakukan setempatsetempat.

c. Caisson tidak dapat digunakan pada permukaan/kontur di bawah garis air yang berbeda-beda.

\section{METODOLOGI PENELITIAN}

\section{Alur Penelitian:}

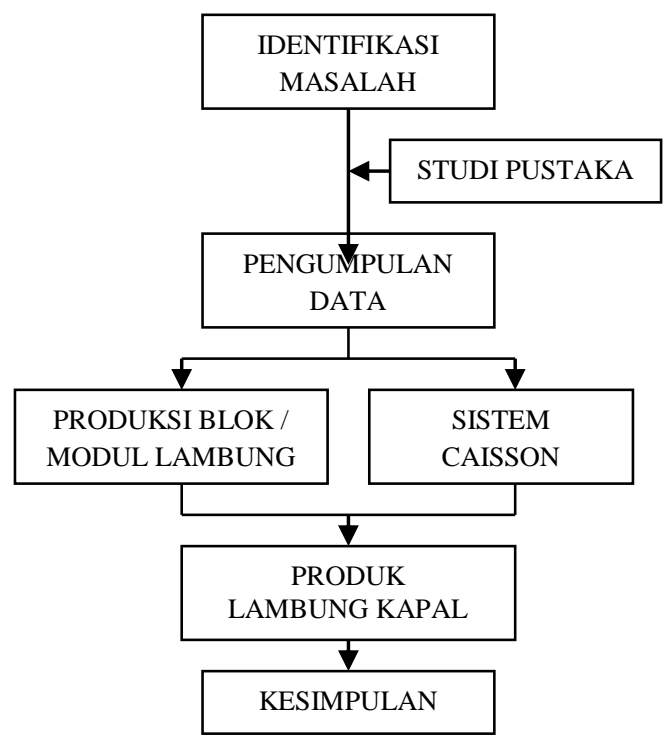

Gambar 2. Bagan Alur Penelitian

\section{ANALISIS DAN PEMBAHASAN \\ Proses Produksi Pembangunan Kapal Sistem Modul}

\section{Perencanaan Produksi}

Perencanaan produksi secara umum adalah meliputi pembagian dan pengurutan pekerjaan mana yang akan dijadikan sebagai petunjuk atau pedoman dalam pelaksanaan pekerjaan produksi.

Pada pembangunan Kapal, dibagi dalam beberapa divisi yaitu:

a. Modul lambung, terdiri:

1) Sub modul lambung bagian belakang

2) Sub modul lambung bagian haluan

b. Modul Kamar Mesin

c. Modul Bangunan Atas (superstructure)

d. Modul Perlengkapan (outfitting)

e. Modul Elektronika, Navigasi dan Komunikasi.

Setiap modul dibagi-bagi ke dalam beberapa bagian blok. Untuk konstruksi lambung dan bangunan atas dibagi sebanyak 21 divisi blok, di mana masing-masing blok merupakan gabungan dari sejumlah seksi (unit).

Pembentukan dan perakitan setiap komponen konstruksi badan kapal maupun outfitting berkaitan Iangsung dengan sarana perbengkelan. Jadi untuk menjamin kesesuaian antara rencana dan pelaksanaan diperlukan kejelasan mengenai jenis pekerjaan dan bengkel pendukung.

Perincian spesialisasi pekerjaan selanjutnya dilakukan dengan pembuatan gambar kerja. Bentuk, ukuran serta detail setiap komponen ditunjukkan dalam gambar kerja.

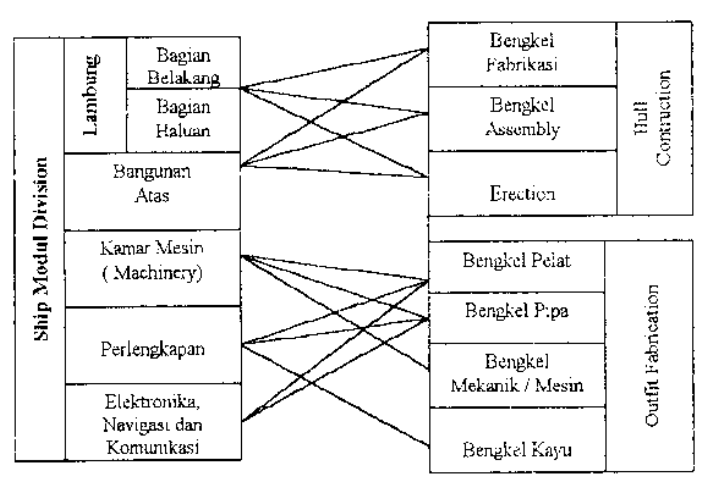

Gambar 3. Diagram Spesialisasi Pekerjaan (Fabrikasi, Assembly dan Erection)

Setelah division blok dan spesialisasi pekerjaan beserta gambar-gambar kerja, petunjuk pelaksanaan dilengkapi pula dengan rencana urutan pembangunan (plan of erection network). Pembangunan 3000 DWT itu akan dilaksanakan dengan mengikuti urutan kerja sebagai berikut:

a. Perakitan blok, yaitu penyambungan seksi-seksi dalam kelompok bioknya masing-masing.

b. Pembentukan modul lambung bagian belakang dan haluan, modul bangunan atas, yaitu penyambungan antara blokblok dalam kelompok modulnya masingmasing.

c. Peluncuran sub modul lambung bagian belakang dan sub modul lambung bagian haluan secara terpisah.

d. Penyambungan modul lambung (Sub modul lambung bagian belakang dan sub modul lambung bagian haluan disatukan).

e. Pemasangan bangunan atas. 
Pekerjaan outfitting meliputi (perlengkapan, elektronika, navigasi dan telekomunikasi) akan dilakukan secara bertahap mengikuti urutan pekerjaan erection, yaitu:
a. Pemasangan pada setiap blok
b. Pemasangan pada setiap modul
c. Pemasangan setelah seluruh badan kapal selesai disambung.

Perencanaan berupa pedoman kerja yang dibuatkan untuk proses penyambungan ini, secara umum dituliskan sebagai berikut:

a. Pedoman pengendalian posisi kedua sub modul lambung sehingga dapat dirapatkan dalam posisi yang sesuai antara yang satu dengan yang lainnya.

b. Pedoman proses pengelasan sehingga perubahan bentuk akibat penyambungan dapat dihindari.

Sejalan dengan rencana penyambungan di air, telah ditetapkan pula untuk menggunakan alat bantu atau sistem caisson. Sistem caisson ini akan dimanfaatkan untuk mendapatkan ruang kerja yang kedap air selama proses pengelasan. Adalah penting untuk diperhatikan bahwa caisson tersebut dapat ditempelkan ke kapal hanya dengan memanfaatkan daya tekan air. Dengan demikian, countour caisson harus sesuai dengan bentuk lambung kapal pada bidang di mana caisson akan ditempelkan. Dimensinya pun harus ditentukan sedemikian hingga diperoleh daya tekan dan ruang kerja yang memadai.

\section{Pelaksanaan Produksi}

Secara umum, pelaksanaan pembangunan kapal diklasifikasikan ke dalam empat jenis pekerjaan yaitu pembuatan mal atau template yang dikerjakan di mould loft, fabrikasi, assembly dan erection, sebagai berikut:

\section{a. Pekerjaan di Mould Loft}

Gambar rencana garis (lines plan) kapal digambar kembali dalam ukuran sebenarnya. Selanjutnya, pembuatan mal yang merupakan tiruan bentuk kapal dengan berdasar pada gambar yang dibuat dengan ukuran sebenarnya. Mal ini akan dipergunakan sebagai pedoman penandaan, pembentukan, pembuatan profil dan pengecekan dalam proses fabrikasi.

b. Fabrikasi

Fabrikasi adalah pekerjaan pemotongan dan pembentukan komponen kontruksi, dikelompokan menjadi dua bagian yaitu:

1) Fabrikasi komponen struktur lambung dan bangunan atas yang dikerjakan di bengkel pelat.

2) Fabrikasi komponen outfit yang dikerjakan pada bengkel pelat, pipa, mekanik/mesin dan kayu.

c. Sub Assembly

Komponen konstruksl lambung ataupun bangunan atas yang telah selesai tahap fabrikasi dibawa ke bengkel assembly untuk digabungkan menjadi seksi.

d. Assembly

Pekerjaan assembly di sini dibedakan antara assembly blok dan assembly modul:

1) Assembly blok adalah penyambungan antara beberapa bagian seksi. Pada tahap ini, sebagian outfit misalnya steel outfit dipasang mengikuti perakitan blok tersebut. Pekerjaan ini masih dilakukan di bengkel assembly.

2) Assembly modul adalah penyambungan antara beberapa blok yang dilakukan di atas landasan pembangunan. Pemasangan beberapa bagian outfit juga dilakukan pada tahap ini.

\section{e. Erection}

Erection adalah proses penyambungan seluruh bagian kapal sehingga menjadi utuh sebagai satu kapal, adalah penyambungan antara modul. Modul lambung (sub modul lambung bagian belakang dan sub modul lambung bagian haluan) setelah diturunkan ke air. Selanjutnya pemasangan bangunan atas serta seluruh perlengkapan atau outfit yang belum terpasang pada tahap sebelumnya.

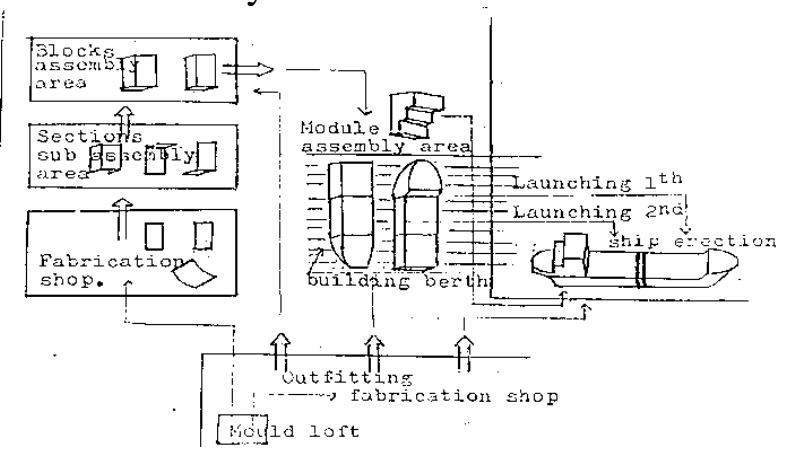

Gambar 4. Bentuk Aliran Pembangunan Kapal (Linerflow of Ship Contruction 
Perhatian terhadap teknik pelaksanaannya, dalam tulisan ini hanya akan tertuju pada proses penyambungan modul lambung kapal di air, yang mana akan dijelaskan di bab berikutnya. Untuk memperoleh pemahaman yang lebih jelas mengenai konsep modul pada pembangunan Kapal III 3000 DWT itu, berikut ini diberikan analisis perbandingan dengan meninjau pada segi disain dan pelaksanaan produksi.

Tabel 1. Perbandingan Sistem Pembangunan Kapal pada Disain Produksi

\begin{tabular}{|l|c|c|c|c|c|c|}
\hline \multirow{3}{*}{$\begin{array}{l}\text { SUBYEK } \\
\text { PERBANDINGAN }\end{array}$} & \multicolumn{5}{|c|}{ SISTEM PEMBANGUNAN } \\
\cline { 2 - 7 } & $\mathrm{A}$ & $\mathrm{B}$ & $\mathrm{C}$ & $\mathrm{C}$ & $\mathrm{D}$ & $\mathrm{E}$ \\
\hline \multicolumn{1}{|c|}{1} & 2 & 3 & 4 & 5 & 6 & 7 \\
\hline A. Desain Produksi & & & & & & \\
1. Division: & $\mathrm{N}$ & $\mathrm{N}$ & $\mathrm{N}$ & $\mathrm{Y}$ & $\mathrm{Y}$ & $\mathrm{Y}$ \\
& $\mathrm{N}$ & $\mathrm{N}$ & $\mathrm{N}$ & $\mathrm{N}$ & $\mathrm{N}$ & $\mathrm{N}$ \\
a. Modul/group & $\mathrm{N}$ & $\mathrm{N}$ & $\mathrm{N}$ & $\mathrm{N}$ & $\mathrm{N}$ & $\mathrm{N}$ \\
b. Blok & $\mathrm{N}$ & $\mathrm{Y}$ & $\mathrm{N}$ & $\mathrm{Y}$ & $\mathrm{Y}$ & $\mathrm{Y}$ \\
c. Seksi & $\mathrm{N}$ & $\mathrm{Y}$ & $\mathrm{N}$ & $\mathrm{Y}$ & $\mathrm{Y}$ & $\mathrm{Y}$ \\
d. Komponen & $\mathrm{N}$ & $\mathrm{Y}$ & $\mathrm{N}$ & $\mathrm{Y}$ & $\mathrm{Y}$ & $\mathrm{Y}$ \\
2. Spesialisasi pekerjaan & $\mathrm{N}$ & $\mathrm{Y}$ & $\mathrm{N}$ & $\mathrm{Y}$ & $\mathrm{Y}$ & $\mathrm{Y}$ \\
3. Gambar kerja & $\mathrm{N}$ & $\mathrm{Y}$ & $\mathrm{N}$ & $\mathrm{Y}$ & $\mathrm{Y}$ & $\mathrm{YN}$ \\
4. Network erection & & & & & & \\
5. Integrasi perencanaan & & & \\
produksi struktur & & & & & & \\
lembaga dengan outfit & & & & & & \\
\end{tabular}

Tabel 2a. Perbandingan Sistem Pembangunan Kapal pada Pelaksanaan Produksi

\begin{tabular}{|c|c|c|c|c|c|c|}
\hline \multirow{2}{*}{$\begin{array}{c}\text { SUBYEK } \\
\text { PERBANDINGAN }\end{array}$} & \multicolumn{6}{|c|}{$\begin{array}{l}\text { SISTEM PEMBANGUNAN } \\
\text { KAPAL }\end{array}$} \\
\hline & A & B & $\begin{array}{l}\mathrm{C} \\
1\end{array}$ & $\begin{array}{l}\mathrm{C} \\
2 \\
\end{array}$ & $\mathrm{D}$ & $\mathrm{E}$ \\
\hline 1 & 2 & 3 & 4 & 5 & 6 & 7 \\
\hline $\begin{array}{l}\text { B. Pelaksanaan Produksi } \\
\text { 1. Struktur lambung: } \\
\text { a. Fabrikasi } \\
\text { b. Sub assembly } \\
\text { - Seksi } \\
\text { - Blok } \\
\text { c. Assembly } \\
\text { - Seksi } \\
\text { - Blok } \\
\text { - Modul/group blok } \\
\text { d. Erection } \\
\text { 2. Out Fitting } \\
\text { a. Fabrikasi } \\
\text { b. Pemasangan pada tahap } \\
\text { - Sub assembly } \\
\text { - Assembly } \\
\text { - Setelah erection } \\
\text { 3. Pengecatan pada tahap } \\
\text { a. Sub assembly } \\
\text { b. Assembly } \\
\text { c. Setelah erection }\end{array}$ & $\begin{array}{l}\mathrm{N} \\
\mathrm{N} \\
\mathrm{N} \\
\mathrm{N}\end{array}$ & $\begin{array}{l}\mathrm{Y} \\
\mathrm{N} \\
\mathrm{N} \\
\mathrm{Y}\end{array}$ & $\begin{array}{l}\mathrm{N} \\
\mathrm{N} \\
\mathrm{N} \\
\mathrm{N}\end{array}$ & $\begin{array}{l}\mathrm{N} \\
\mathrm{N} \\
\mathrm{N} \\
\mathrm{N}\end{array}$ & $\begin{array}{l}\mathrm{N} \\
\mathrm{N} \\
\mathrm{N} \\
\mathrm{N}\end{array}$ & $\begin{array}{l}\mathrm{N} \\
\mathrm{N} \\
\mathrm{Y} \\
\mathrm{Y}\end{array}$ \\
\hline
\end{tabular}

Tabel 2b. Perbandingan Sistem Pembangunan Kapal pada Pelaksanaan Produksi (lanjutan)

\begin{tabular}{|c|c|c|c|c|c|c|}
\hline \multirow[t]{2}{*}{$\begin{array}{c}\text { SUBYEK } \\
\text { PERBANDINGAN }\end{array}$} & \multicolumn{6}{|c|}{$\begin{array}{c}\text { SISTEM PEMBANGUNAN } \\
\text { KAPAL }\end{array}$} \\
\hline & $\mathrm{A}$ & B & $\begin{array}{l}\mathrm{C} \\
1\end{array}$ & $\begin{array}{l}\mathrm{C} \\
2\end{array}$ & $\mathrm{D}$ & $\mathrm{E}$ \\
\hline 1 & 2 & 3 & 4 & 5 & 6 & 7 \\
\hline $\begin{array}{l}\text { 4. Tempat perakitan: } \\
\text { a. Fabrikasi } \\
\text { b. Blok di }\end{array}$ & $\mathrm{N}$ & $\mathrm{Y}$ & $\mathrm{N}$ & $\mathrm{Y}$ & $\mathrm{Y}$ & $\mathrm{Y}$ \\
\hline
\end{tabular}

\begin{tabular}{|l|c|c|c|c|c|c|}
\hline - Bengkel & $\mathrm{N}$ & $\mathrm{N}$ & $\mathrm{N}$ & $\mathrm{N}$ & $\mathrm{N}$ & $\mathrm{N}$ \\
c. Pelataran/diatas lori & $\mathrm{N}$ & $\mathrm{N}$ & $\mathrm{N}$ & $\mathrm{N}$ & $\mathrm{N}$ & $\mathrm{Y}$ \\
- Podul group & & & & & & \\
- Pelataran/diatas lori & $\mathrm{N}$ & $\mathrm{N}$ & $\mathrm{N}$ & $\mathrm{N}$ & $\mathrm{N}$ & $\mathrm{N}$ \\
d. Erection kapal di & $\mathrm{N}$ & $\mathrm{N}$ & $\mathrm{N}$ & $\mathrm{N}$ & $\mathrm{N}$ & $\mathrm{N}$ \\
$\begin{array}{l}\text { Fabrikasi } \\
\text { - Building berth }\end{array}$ & & & & & & \\
- Air & $\mathrm{N}$ & $\mathrm{Y}$ & $\mathrm{N}$ & $\mathrm{N}$ & $\mathrm{N}$ & $\mathrm{N}$ \\
\end{tabular}

Keterangan:

$\mathrm{A}=$ Sistem komponen

$\mathrm{B}=$ Sistem seksi

$\mathrm{C} 1=$ Sistem blok

$\mathrm{C} 2=$ Sistem blok dengan group blok

$\mathrm{D}=$ Sistem modul

$\mathrm{E}=$ Sistem modul yang diterapkan

$\mathrm{Y}=\mathrm{Ya}$

$\mathrm{N}=$ Tidak

YN = Ya, tapi tak sepenuhnya

\section{Perencanaan Sistem Caisson}

\section{Sistem Caisson Sebagai Alat Bantu}

Caisson yang dimaksudkan di sini dikonstruksi menyerupai bentuk huruf "L" untuk bisa menempel secara sempurna pada dasar dan sisi kapal yang silindris.

Caisson ini merupakan kotak memiliki ukuran panjang, lebar, dan tinggi, pada bagian yang akan menempel dan mempunyai garis bentuk yang sama dengan permukaan luar lambung kapal di mana caisson akan ditempelkan. Caisson diturunkan ke air, kemudian dilekatkan ke badan kapal. Ruang kerja yang kedap diperoleh setelah air dipompa keluar dari dalam ruang yang dibatasi oleh bidang lambung kapal dengan dinding caisson tersebut. Kekedapan kompartemen ini tetap dapat dipertahankan karena adanya gaya tekan yang cukup kuat oleh caisson terhadap dasar dan sisi kapal yang ditransformasikan dari daya apung caisson itu sendiri.

\section{Bentuk dan Dimensi}

Bentuk badan caisson dapat dibayangkan dengan dua sistem proyeksi bidang. Keduanya adalah bidang vertikal, tetapi yang satu pada arah memanjang dan yang lainnya pada arah melintang, sebagai berikut:
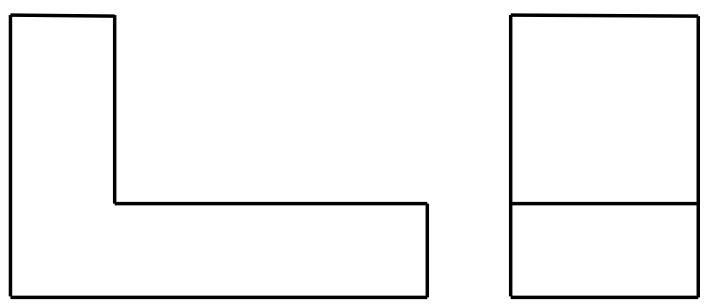
a. Arah memanjang
b. Arah melintang

Gambar 5. Proyeksi Bentuk Bidang Caisson 
Elemen bentuk caisson pada dasarnya adalah:

1. Bagian yang akan menempel dengan sebutan main countour (garis bentuk utama). Garis bentuk ini harus sama dengan garis bentuk bidang sisi dan dasar kapal di mana caisson akan ditempelkan.

2. Bottom atau dasar dengan bidang yang horizontal. Bagian dasar ini merupakan penghubung antara sisi-sisi caisson.

3. Sisi, yaitu bidang vertikal badan caisson. Ada empat bidang sisi caisson yang masingmasing disebut sisi kiri, kanan, depan dan belakang.

Elemen dimensi caisson dengan cara penentuannya ditunjukkan sebagai berikut:

1. Panjang yang terdiri dari dua jenis ukuran yaitu:

a. Panjang Keseluruhan (La) yaitu panjang antara sisi depan sampai dengan sisi belakang.

b. Panjang Utama (Lm) yaitu ukuran panjang bagian caisson yang menempel dinding kapal. Ukuran panjang utama ini didasarkan pada lebar kapal (B) dimana caisson akan digunakan dengan ketentuan Lm lebih besar dari $1 / 2 \mathrm{~B}$. Harga La lebih besar dari Lm dengan selisih minimal merupakan ukuran yang efektif untuk jalan masuk ke caisson.

2. Lebar (B) yaitu dimensi melintang yang diukur dari sisi kiri ke sisi kanan. Ukuran ini ditentukan dengan pertimbangan terdapatnya ruang kerja di dalam caisson yang memadai.

3. Tinggi adalah dimensi vertikal dengan jenisjenis ukuran sebagai berikut:

a. Tinggi keseluruhan (Ha) yaitu jarak antara bagian dasar dengan bagian teratas atau puncak caisson

b. Tinggi kotak utama $(\mathrm{Hb})$ yaitu panjang garis vertikal antara garis dasar dengan garis panjang utama. Ukuran tinggi ini dikurangi dengan tinggi tangki dasar merupakan dimensi ruang kerja sehingga dalam penentuannya didasarkan pula pada pertimbangan ruang kerja yang memadai.

c. Tinggi utama (Hm), Panjang bagian yang akan menempel pada arah vertikal. Harga $\mathrm{Hm}=\mathrm{Ha}-\mathrm{Hb}$.

d. Sarat yaitu tinggi pembenaman dengan jenis-jenis ukuran sebagai berikut :
1) Sarat air keseluruhan (Ta) yaitu jarak vertikal antara garis dasar dengan garis air yang direncanakan.

2) Sarat utama (Tm) yaitu jarak vertikal antara garis panjang utama dengan garis air yang direncanakan. Sarat utama ini sama dengan sarat kapal di mana caisson tersebut akan digunakan.

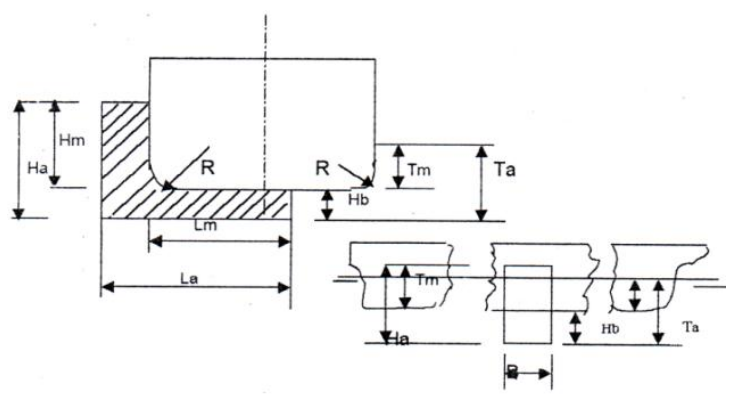

Gambar 6. Dimensi Caisson

Di samping dimensi yang disebutkan di depan, ada dimensi lain adalah volume (V) dan displacement (D).

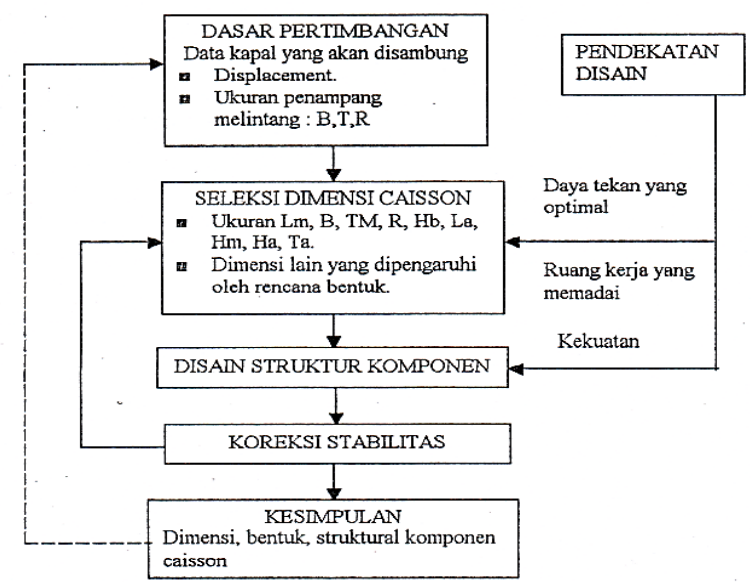

Gambar 7. Bagan Alir Prosedur Perencanaan Sistem Caisson

\section{Penyambungan Lambung Kapal di Air}

Modul lambung kapal 3000 DWT pada waktu pembangunannya dibagi menjadi dua bagian, yaitu sub modul lambung bagian haluan dan belakang. Daerah sambungan antara kedua sub modul ini berada pada bagian tengah kapal (ship pararel middle body). Keduanya akan disambung di air dengan menggunakan alat bantu sistem caisson setelah masing-masing diluncurkan secara terpisah.

Ada 4 kriteria utama penyambungan, yaitu:

1. Bagian yang akan disambung (pertemuan sambungan), harus memiliki bentuk dan dimensi yang sesuai satu dengan yang 
lainnya. Diperlukan pengawasan ketelitian geometris pada proses perakitan unit.

2. Pekerjaan las dapat terlaksana secara sempurna atau dengan kata lain memenuhi persyaratan teknik pengelasan bangunan kapal sebagaimana disyaratkan oleh peraturan Biro Klasifikasi.

3. Defleksi lunas dalam batas yang disyaratkan. Untuk kapal dengan Lpp kurang dari atau sama dengan 100 meter, defleksi maksimum yang diizinkan adalah tidak lebih dari $25 \mathrm{~mm}$.

4. Tidak terjadi perubahan bentuk (geometris) setelah proses penyambungan. Perlu diperhatikan bahwa perubahan bentuk disebabkan oleh kesalahan penyetelan dan urutan pengelasan yang salah.

\section{Perencanaan Penyambungan Lambung}

1. Penentuan Jumlah dan Dimensi Engsel

Pada waktu penyambungan lambung Kapal dibutuhkan enam buah engsel yang digunakan sesuai dengan ukuran dan bentuk. sebagai berikut:

a. Momen yang terjadi pada daerah sambungan dimana engsel dipasang adalah sebesar:

$$
\begin{aligned}
\mathrm{M}= & 103,5 \text { ton.m } \\
\mathrm{n}= & \text { jumlah engsel }=6 \\
\mathrm{l}= & \text { jarak kerja momen terhadap titik } \\
& \text { tumpu }=7,97 \mathrm{~m}
\end{aligned}
$$

b. Beban yang bekerja pada setiap engsel adalah:

$$
\begin{aligned}
\mathrm{P} & =(\mathrm{M}) /(\mathrm{n} \cdot \mathrm{l}) \\
& =(103,5) /(6.7,97) \\
& =3,2 \text { Ton }
\end{aligned}
$$

c. Tegangan dihitung dengan rumus:

$\sigma=(\mathrm{P}) /(\mathrm{A})$

Catatan:

$\mathrm{P}=$ beban $(\mathrm{kg})$, dan $\mathrm{A}=$ luas penampang $\left(\mathrm{cm}^{2}\right)$.

Tegangan yang terjadi pada setiap bagian struktur engsel adalah:

- Pada batang A, $\sigma=53,156 \mathrm{~kg} / \mathrm{cm}^{2}$

- Pada batang B, $\sigma=48,500 \mathrm{~kg} / \mathrm{cm}^{2}$

- Tegangan dukungan antara pen dengan batang A, $\sigma \mathrm{a}=152 \mathrm{~kg} / \mathrm{cm}^{2}$

- Tegangan dukungan antara pen dengan batang B, $\sigma \mathrm{b}=106,67 \mathrm{~kg} / \mathrm{cm}^{2}$

- Tegangan geser ganda pada pen sebesar

$$
\sigma=36,22 \mathrm{~kg} / \mathrm{cm}^{2}
$$

Tegangan yang diizinkan adalah sebesar 1200 $\mathrm{kg} / \mathrm{cm}^{2}$.

\section{Penetapan Prosedur Pengelasan}

Prosedur pengelasan, pada dasarnya meliputi beberapa hal sebagai berikut:

1. Pemilihan bahan las (kawat las, gas dan lainlain);

2. Penentuan tipe sambungan las (menumpu, jalur, komposisi dan sebagainya);

3. Penentuan urutan pengelasan (Welding Sequence);

4. Pemilihan juru las.

Urutan pengelasan harus dibuat sederhana dan praktis.
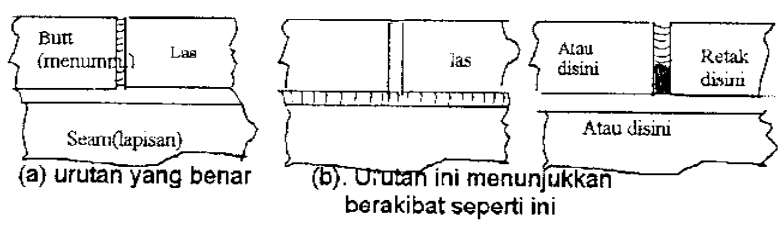

Gambar 7. Urutan Pengelasan

Prinsip dasar suatu urutan pengelasan diperlihatkan pada gambar di atas. Gambar ini mengilustrasikan interseksi $\mathrm{T}$ yang sederhana dari suatu sambungan las menumpu (butt) dan las berlapis (seam). Untuk gambar (a) dan (b) diberikan penjelasan sebagai berikut:

1. Kedua pelat bagian atas dapat bergerak secara bebas sebagai akibat dari penyusutan karena pengelasan pertama. Jika gabungan pelat ini dilas pada pelat alas, keseluruhan pelat dapat bergerak dengan relatif bebas.

2. Pengelasan yang pertama akan menjaga pelat dari gerakan pada waktu pengelasan kedua dan mempertahankan tingkat pengekangan khusunya pada bagian interseksi.

\section{Pelaksanaan Penyambungan}

Pelaksanaan penyambungan modul lambung kapal di air dikelompokan sebagai berikut:

1. Pengendalian posisi kedua sub modul lambung kapal sedemikian rupa hingga dapat dirapatkan dengan posisi yang sesuai antara satu dengan lainnya.

2. Pengkakuan hubungan antara kedua bagian lambung seperti yang dimaksudkan di atas dengan pemasangan penguat sementara (temporary bracing).

3. Pemasangan sistem caisson diikuti dengan proses pengelasan.

4. Pemeriksaan hasil sambungan las. 


\section{Penyesuaian Posisi Kedua Modul Lambung}

Penyesuaian posisi sampai seluruh bagian sambungan dapat dirapatkan, dilakukan dengan sistem pem-ballast-an, sebagai berikut:

1. Sejumlah ballast air dimasukkan ke salah satu bagian modul lambung sampai pada batas keadaan dimana sumbu lubang engsel berada pada satu garis.

2. Bila pasangan-pasangan setiap engsel telah terpasang, secara perlahan-lahan ballast air pada kedua bagian dasar ganda masing-masing modul lambung tersebut dikeluarkan dengan demikian bagian bawah kapal akan menyatu.

\section{Pemasangan Sistem Caisson}

Urutan unjuk kerja pengendalian atau pemasangan sistem caisson pada bagian lambung kapal yang akan disambung adalah sebagai berikut:

1. Caisson diturunkan ke air dan selanjutnya dilakukan pem-ballast-an (ballast air di dalam tangki untuk mencapai kondisi lunas rata even keel). Pem-ballast-an hanya dilakukan apabila sistem caisson tersebut tidak even keel.

2. Pem-ballast-an dengan pengisian air sepenuhnya pada ruang kerja caisson.

3. Pengisian ballast air pada tanki-tanki caisson. Berat ballast diperhitungkan sampai caisson terbenam dengan kedalaman di bawah lambung kapal.

4. Caisson dirapatkan ke lambung kapal sesuai posisi yang telah ditetapkan.

5. Sebahagian atau seluruh air yang ada di dalam tanki-tanki caisson dipompa keluar. Dengan demikian caisson mulai naik keatas, menempel dan menekan lambung kapal.

6. Air yang torjebak di ruang kerja caisson dapat dikosongkan atau dipompa ke luar sehingga tekanan caisson terhadap lambung kapal semakin kuat.

7. Bila tekanan caisson terhadap lambung kapal terlalu besar, maka tanki diisi dengan air untuk mengurangi tekanan sebatas yang dibutuhkan.

\section{Pengelasan dan Pemeriksaan Las}

Pengelasan dilaksanakan mengikuti pemasangan caisson berdasar pada prosedur pengelasan yang telah ditetapkan.

Keputusan baik atau tidaknya hasil sambungan dapat dipastikan setelah pemeriksaan klasifikasi las. Dalam hal ini adalah kewenangan pihak Biro Klasifikasi. Mengutip ketentuan pengujian las yang dinyatakan dalam Buku
Pedoman Pengendalian dan Jaminan Mutu ( PPJM ), BPPT, Kelompok Kerja, Pengadaan Kapal Niaga Terpadu, dikemukakan beberapa hal pokok sebagai berikut:

1. Pemeriksaan sambungan las lambung kapal dengan menggunakan radiografi (X-Ray), harus sesuai dengan peraturan Biro Klasifikasi Indonesia atau sesuai dengan standar lain yang diakui.

2. Prosedur radiografi menurut BKI:

a. Permukaan sebelah luar dan sebelah dalam dari lajur las yang akan diradiografi harus bersih dari cacat proses (processing defect).

b. Film radiografi harus diberi tanda sehingga menunjukkan dengan jalas nama (nomor, kode) kapal dan lokasi yang diradiografi.

3. Jumlah titik pengujian radiografi dalam daerah tengah kapal $0,4 \mathrm{~L}$, paling sedikit sama dengan jumlah $A_{D}$ sebagai berikut:

$A_{D}=0,8 A_{L} \cdot C p\left(A_{B}-C_{B}+A_{H} \cdot C_{H}\right)$

Dimana;

$\mathrm{A}_{\mathrm{L}}=\left(\mathrm{L} .10^{3}\right) /\left(16 . \mathrm{a}_{0}\right)$

$\mathrm{L}=$ Panjang kapal (m)

$\mathrm{A}_{0}=2,5 \mathrm{~L}+410.1000(\mathrm{~mm})$

$\mathrm{Cp}=1,5 ;$ untuk gading-gading melintang

$\mathrm{A}_{\mathrm{B}}=\mathrm{B} / 2,5 ; \mathrm{B}=$ Lebar kapal $(\mathrm{m})$

$\mathrm{C}_{\mathrm{B}}=1,5$

$\mathrm{A}_{\mathrm{H}}=\mathrm{H} / 2,5 ; \mathrm{H}=$ tinggi $\operatorname{kapal}(\mathrm{m})$

$\mathrm{C}_{\mathrm{H}}=1,3$

Rumus di atas di dapat dari buku BKI Jilid V (Bahan dan Las).

4. Pengujian radiografi dalam daerah tengah kapal 0,4 L adalah terutama pada lokasilokasi perpotongan las lintang dengan las bujur pada lajur atas, lajur bilga, geladak penguat, pelat lunas, sekitar sudut ambang palka pada geladak utama sekitar bracket bangunan atas.

5. Cacat las yang ditolak adalah retak, kurang berfungsi, terak yang panjang dan berpori yang besar.

6. Perbaikan dari las yang ditolak:

a. Bila cacat tersendiri atau sejumlah cacat yang ditolak terpusat pada satu lokasi pada film radiografi, maka hanya cacat tersebut yang perlu diperbaiki.

b. Bila suatu atau sejumlah cacat yang ditolak terletak pada ujung film dan lanjutan cacat yang ditolak tidak dapat ditentukan dari film yang ada, maka perlu diadakan pengujian radiografi tambahan. 
c. Bila film radiografi menunjukkan adanya cacat yang ditolak, maka pada lokasi tersebut harus dibongkar sampai cacatnya hilang kemudian diperbaiki kembali.

d. Semua las yang diperbaiki harus diuji radiografi kembali.

Pengujian sambungan las antara sub modul lambung bagian haluan dan buritan Kapal:

1. Pengujian radiografi pada daerah sambungan las dilakukan terhadap 30 buah titik. Bila dibandingkan dengan jumlah titik peninjauan yang diharuskan pada bagian tengah kapal 0,4 L yaitu 144, maka jumlah tersebut di atas telah cukup meyakinkan.

2. Dari 30 titik yang diuji ada 5 buah titik yang ditolak dengan keterangan perbaikan sebagai berikut :

a. Dua buah titik diperbaiki tanpa diuji kembali.

b. Dua buah titik diterima setelah pengujian radiografi yang kedua.

c. Satu buah titik diterima setelah pengujian radiografi yang ketiga.

Dari hasil pengujian tersebut, telah dapat dinyatakan bahwa sambungan las antara sub modul lambung kapal bagian haluan dan buritan memenuhi ketentuan yang disyaratkan oieh Biro Klasifikasi Indonesia, walaupun operasi penyambungannya dilakukan di air. Dengan menggunakan alat bantu sistem caisson adalah sama dengan pelaksanaan penyambungan di darat atau di atas building berth. Kekhususan penyambungan lambung kapal di air hanya terletak pada dua hal pokok:

1. Peluncuran badan kapal yang terbagi dalam dua bagian.

2. Unjuk kerja dalam mempertemukan bagian sambungan lambung kapal dilaksanakan dengan menggunakan prinsip-prinsip dinamika kapal di dalam air.

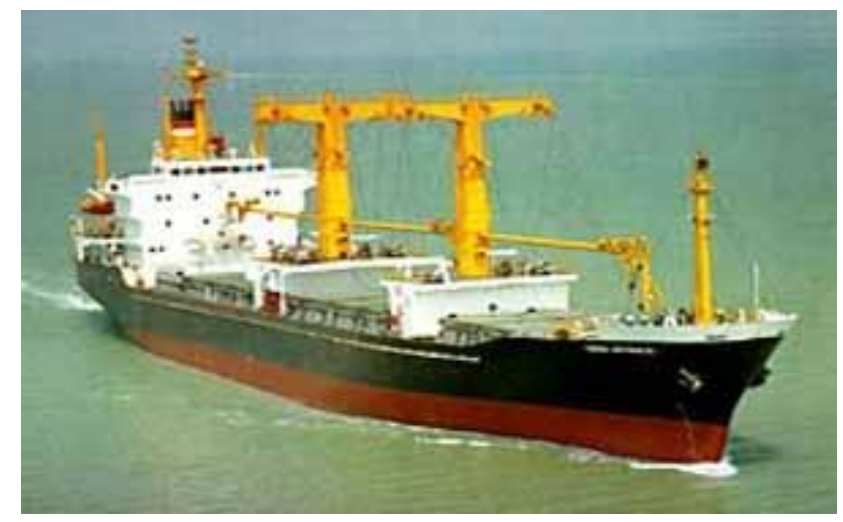

\section{KESIMPULAN}

1. Pengembangan cara pembangunan kapal yaitu penyambungan lambung kapal di air dengan menggunakan alat bantu sistem caisson. Dengan cara ini, daya produksi galangan dapat ditingkatkan. Dengan fasilitas peluncuran yang hanya mampu melayani bangunan kapal dengan panjang maksimal 68 $\mathrm{m}$, telah mampu membangun Kapal dengan panjang Lpp $=92,00 \mathrm{~m}$.

2. Dalam hal penyambungan lambung kapal di air, sistem caisson berfungsi untuk membebaskan lambung kapal di sekitar daerah sambungan dari genangan air. Dengan demikian, pengelasan atau penyambungan dapat dilakukan seperti biasa sebagaimana halnya di darat.

3. Pemeriksaan terhadap pekerjaan pengelasan di air adalah sama pada saat kapal dikerjakan di darat.

4. Dari segi teknik, dapat diyakinkan bahwa penyambungan lambung kapal di air memungkinkan untuk diterapkan untuk reparasi konversi misalnya pada pekerjaan memperpanjang kapal.

\section{DAFTAR PUSTAKA}

Attwood Edward L, (1993), Theoritical Naval Architecture, Grenwich.

Biro Klasifikasi Indonesia, (2006), Regulasi Konstruksi Kapal Baja.

D'arcangelo Amello M, (1977), Ship Design and Contruction, SNAME.

"Encyclopedia dictionary" online di www.wikipedia.org

Kahar Nilyard, (1986), Study Kebijaksanaan Ilmu Pengetahuan dan Teknologi (Kasus Alih Teknologi di Bidang Industri Kapal), LIPI.

Ronny D. Tulak, (2013), Teknologi Produksi Kapal, Fakultas Teknik - UPNVJ

Santoso I Made Gusti, (1982), Teori Bangunan Kapal 2, Edisi Pertama Departemen Pendidikan dan Kebudayaan, Jakarta.

Wiryosumarto, Harsono, dan Toshie Okumura, (2000), Teknologi Pengelasan Logam, Cetakan 8, Pradya Paratama, Jakarta. 